\title{
CHALLENGES OF ELEPHANT CONSERVATION: INSIGHTS FROM ORAL HISTORIES OF COLONIALISM AND LANDSCAPE IN TSAVO, KENYA*
}

\author{
PETER NGUGI KAMAU and ANDREW SLUYTER
}

\begin{abstract}
Understanding the reasons for conflict between elephants and people who live adjacent to conservation areas remains key to recruiting them as allies in preserving elephant populations. The Tsavo region of Kenya has become a notable battleground for elephant conservation in East Africa, characterized by ivory poachers, crop damages by elephants in communities adjacent to parks, and electric fencing to control human and wildlife mobility. Oral histories of six ethnic groups reveal how such human-elephant conflict emerged during colonial times through a landscape transformation process involving elephants, livestock, people, and vegetation. The general trend over the past two centuries involves a transition from a precolonial modality characterized by human and elephant mobility to their increasing immobility, spatial separation, and conflict. Understanding of the historical emergence of that conflict forces recommendation of a change in policy direction, from further reducing mobility to restoration of mobility and spatial reintegration of people in parks. Keywords: colonialism and landscape, East Africa, elephant conservation, historical political ecology.
\end{abstract}

7 he relationship between wildlife conservation areas and the people who live adjacent to them has received much attention from political ecologists and others, including the prominent topic of elephant conservation in Africa (Akama, Lant, and Burnett 1996; Neumann 1998; Hoare and Du Toit 1999; Smith and Kasiki 2000; Robbins 2004; Robbins and others 2009; Lunstrum 2014). The findings generally suggest that where conservation areas neighbor settlements, the major challenge in conserving elephant populations remains the complex and fraught relationship between elephants and their human neighbors. In particular, human-elephant conflict tends to persist where conservation areas have been established through forced resettlement of former inhabitants into neighboring areas. But even where forced resettlement has not occurred, conflict tends to arise wherever a majority of people living adjacent to conservation areas depend directly on crops, livestock, forest products, and wildlife for their livelihoods. Legal restrictions on the use of resources within conservation areas results in confrontations with managers, such as park wardens (Adam and McShane 1996; Brechlin and others 2003; Lepp and Holland

\footnotetext{
${ }^{*}$ We thank the people of the Tsavo region, the staff of the Kenya National Archives, and officials of the Kenya Wildlife Service for their assistance during field and archival research. We also thank the Cultural Historical Collaborative of the Geography and Anthropology Department of the Louisiana State University, Kent Mathewson, Brian J. Marks, Mark J. Schafer, and the anonymous referees for their comments on previous versions of this paper.
}

3f Dr. Peter Ngugi Kamau, Karatina University, Kenya. P.O Box 1957-10101 Karatina, Kenya; [wakamau2011@gmail.com]. Dr. Andrew SLuYter, Louisiana State University, Department of Geography and Anthropology, 227 Howe-Russell-Kniffen Building, Baton Rouge, Baton Rouge, LA 70808, USA; [asluyter@lsu.edu]. 
2006). And damages to crops by wildlife that stray from conservation areas into adjacent farmlands results in outright animosity toward animals such as elephants (Paraskevopoulos, Korfiatis, and Pantis 2003). Understanding the origins of such conflicts and overcoming them in order to recruit people who live adjacent to conservation areas as allies in protecting elephant populations thus remains a key research goal.

The case of Tsavo, Kenya, has the potential to provide many insights into the shifting relationship between elephants and people. Over the past half century, the Tsavo region has become a principal battleground for wildlife conservation in East Africa, with more than 10,000 elephants roaming the some $20,000 \mathrm{~km}^{2}$ of its parks, rampant ivory poaching, and many claims for crop damages by elephants among farmers neighboring its parks (KWS 2008; Ngene and others 2013). Tsavo receives immense attention nationally and internationally, including a planned film by Angelina Jolie about the life and work of Richard Leakey, the son of the paleoanthropologists Mary and Louis Leakey as well as the founding director of the Kenya Wildlife Service (KWS). Leakey, a leading promoter of technologies like electric fencing, militarized antipoaching units, and ivory bonfires has become an international proponent of the Yellowstone Model, which assumes that wildlife conservation requires the virtual exclusion of people from parks to create putatively natural ecosystems (Moore 2009; Lunstrum 2014).

Most research on human-elephant relations in Tsavo is apolitical and ahistorical, does not problematize conservation policies, and has focused on mitigating problems such as crop damages (Ngure 1995; Kasiki 1998). Yet Tsavo's human inhabitants maintain richly detailed oral histories that enable the reconstruction of human-elephant-landscape transformations through precolonial (before 1895), colonial (1895-1963), and postcolonial (after 1963) times.

Oral histories reveal that in precolonial Tsavo, there was an assemblage of interactions based on fluidity and permanent mobility that had positive effects on humans, elephants, and the general ecology. In precolonial Tsavo, there was mutual cohabitation of several modes of production (hunters and gatherers, pastoralists, and agriculturalists), and cultural perspectives that supported the coexistence of humans and elephants in the same landscape. Our analysis of oral histories and archival records shows that colonial and postcolonial ways of managing lands and people disrupted precolonial human-elephant interactions, effectively and symbolically separating humans from elephants. This separation is the root cause of human-elephant conflicts in Tsavo.

The reconstructions of interwoven natural and social, as well as material and discursive, processes remain key to understanding the historical emergence of current global conflicts over nature. In this study, we focus on conflicts between the human and elephant inhabitants of Tsavo. The colonial triangle model, first developed to understand the relationship between colonialism, landscape, and development in Mexico but since applied elsewhere, helps to disentangle the key material and discursive strands in that natural/social process (Sluyter 2001, 2002). 


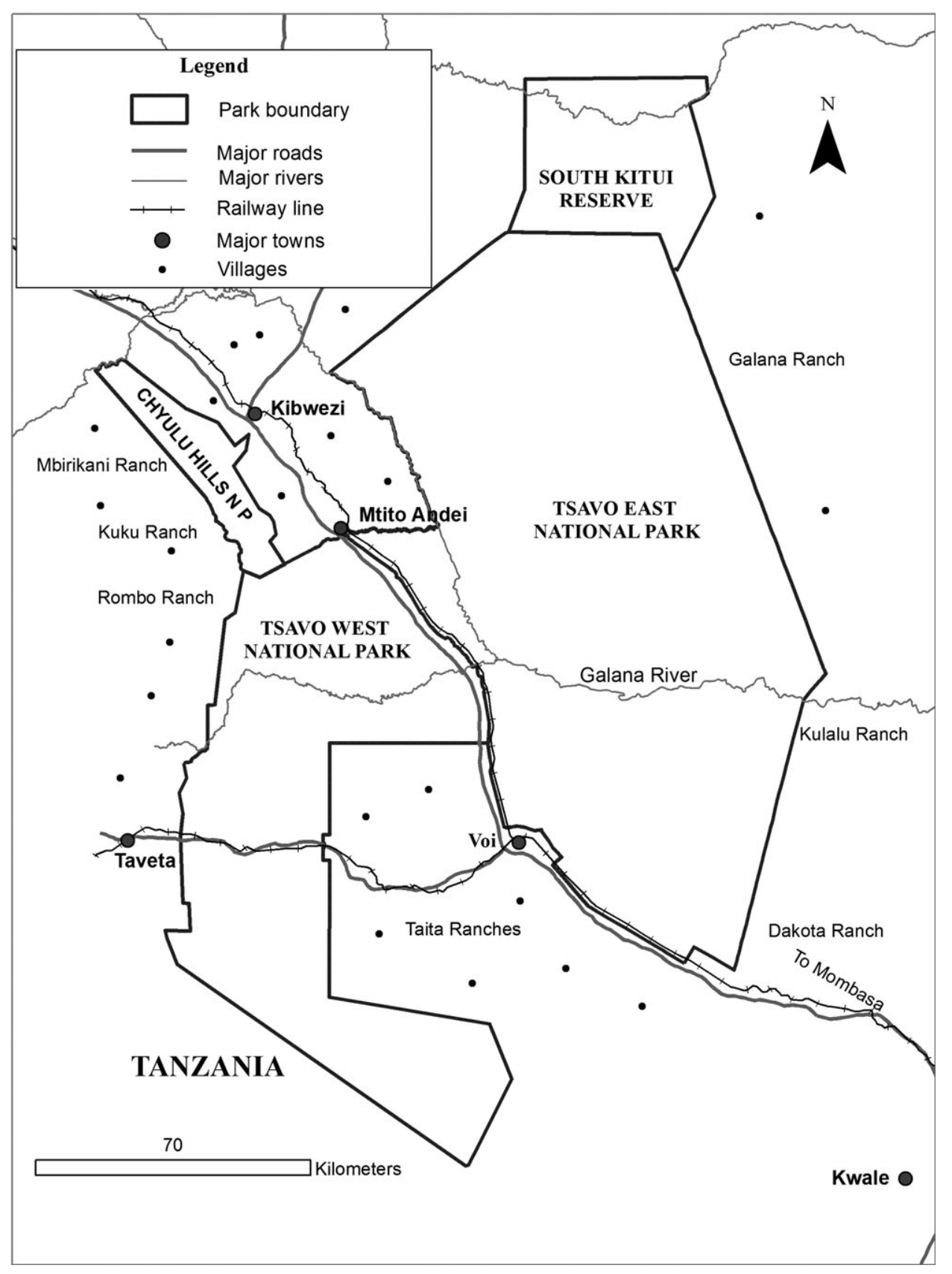

FIG. 1-Map of the Tsavo region showing parks and adjacent communities. (Source: KWS GIS data; drafted by the authors, 2017). 
Ultimately, attention to such historical processes offers alternative possibilities for elephant conservation in Tsavo and beyond (Adams 2003).

\section{Tsavo, Oral Histories, and Archives}

The Tsavo region covers parts of five counties in southern Kenya (Figure 1). This research focuses on areas within and adjacent to three national parks in the Tsavo region: Tsavo East, Tsavo West, and Chyulu Hills National Parks (TENP, TWNP, and CHNP). TENP and TWNP are the two largest national parks in Kenya and account for about forty percent of the total protected area in the country (Njogu 2004). The Mombasa-Uganda Railway marks the division between TENP and TWNP, originally established as one park in 1948 but divided into western and eastern units to facilitate administration of such an immense area. CHNP was established in 1983 to the north of TWNP.

Low elevation plains punctuated by inselbergs - steep, isolated hills — characterize Tsavo (Figure 2). Savannah covers the lowland plains, with open grassland in some zones but mainly a patchy mixture of grassland, shrubland, and open woodland dominated by thorny, drought-tolerant acacia and myrrh species (Acacia spp., Commiphora spp.). Compared to the plains, the hills have higher precipitation and deeper, more fertile soils that support montane

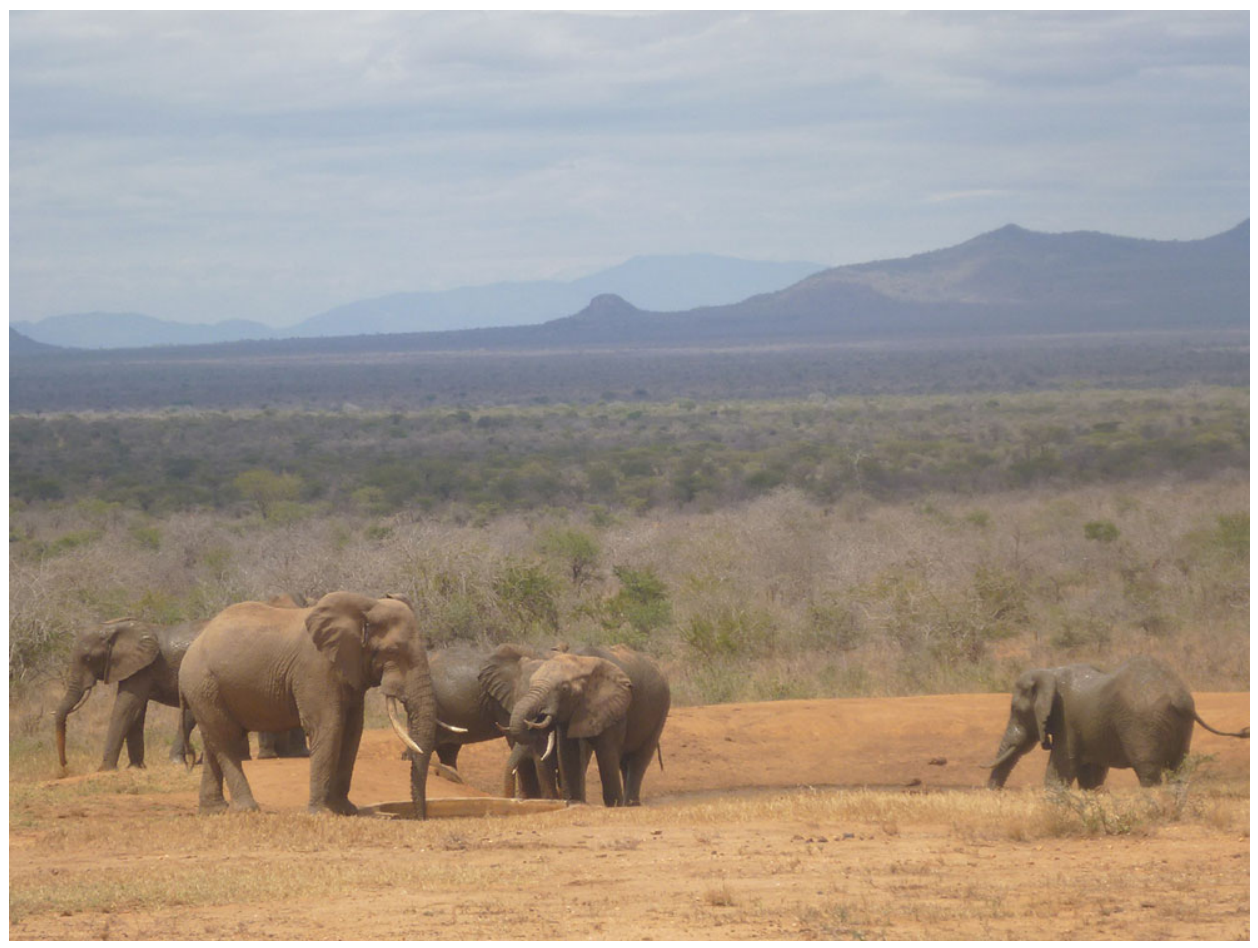

FIG. 2-Landscape with elephants in foreground and inselbergs in background. (Source: Photograph by the authors, June 2015). 
evergreen forest. Many animal species occur, including the iconic big five, a wildlife designation originally derived from their status among big game hunters: elephants (Loxodonta africana), buffaloes (Syncerus caffer), lions (Panthera leo), leopards (Panthera pardus pardus), and black rhinoceroses (Diceros bicornis) (Wijngaarden 1985).

Six ethnic groups inhabited Tsavo during precolonial times: the Kamba, Taita, Taveta, Maasai, Waata, and Orma. Since Kenyan independence in 1963, the human population of the region has grown rapidly-from about 150,000 to nearly 800,000 - and become much more ethnically diverse (Table 1). Presently, the majority of Taita, Taveta, Waata, and Kamba are farmers who also keep small herds of livestock. The Maasai and Orma remain predominantly pastoralists, although declining access to pasture and persistent droughts have forced some to become farmers. About twenty percent of the current population is involved in trade and commerce or employed in tourism and commercial agriculture (KNBS 2010). The majority of inhabitants live on less than US\$2.00 per day and lack domestic water and electricity supplies. The Waata, the smallest of the original six ethnic groups, disproportionately suffer impoverishment (Figure 3). During severe droughts, at least 40 percent of the Tsavo population relies on relief from government agencies and nongovernmental aid organizations. Given the social and economic marginalization of so many, legal prohibitions on the use of park resources and depredation of crops by elephants that stray beyond park boundaries entail serious consequences for livelihoods.

In order to reconstruct and understand human-elephant-landscape interactions over the past two centuries, the authors conducted oral history interviews over 2014-2015 with a total of seventy-two people over the age of eighty from eighteen villages equally distributed among all six ethnic groups. Although anonymized with respect to name and village, we report their ethnic affiliations because it provides essential context for interpreting the oral histories.

Archival records, traveler accounts, and other published documents such as ethnographies complement the oral histories. The Kenya National Archives (KNA) in Nairobi contain the vast majority of relevant archival materials.

Table 1-Human population of the Tsavo Region, 1960-2016.

\begin{tabular}{lc}
\hline \hline YEAR & ENUMERATION* \\
\hline 1960 & 149,647 \\
1979 & 323,867 \\
1989 & 430,449 \\
1999 & 539,300 \\
2009 & 670,849 \\
2016 & $777,979^{* *}$ \\
\hline
\end{tabular}

${ }^{* *}$ Estimate based on the 2009 enumeration multiplied by the national population growth rate of 2.5 percent.

*Source: KNBS 2010. 


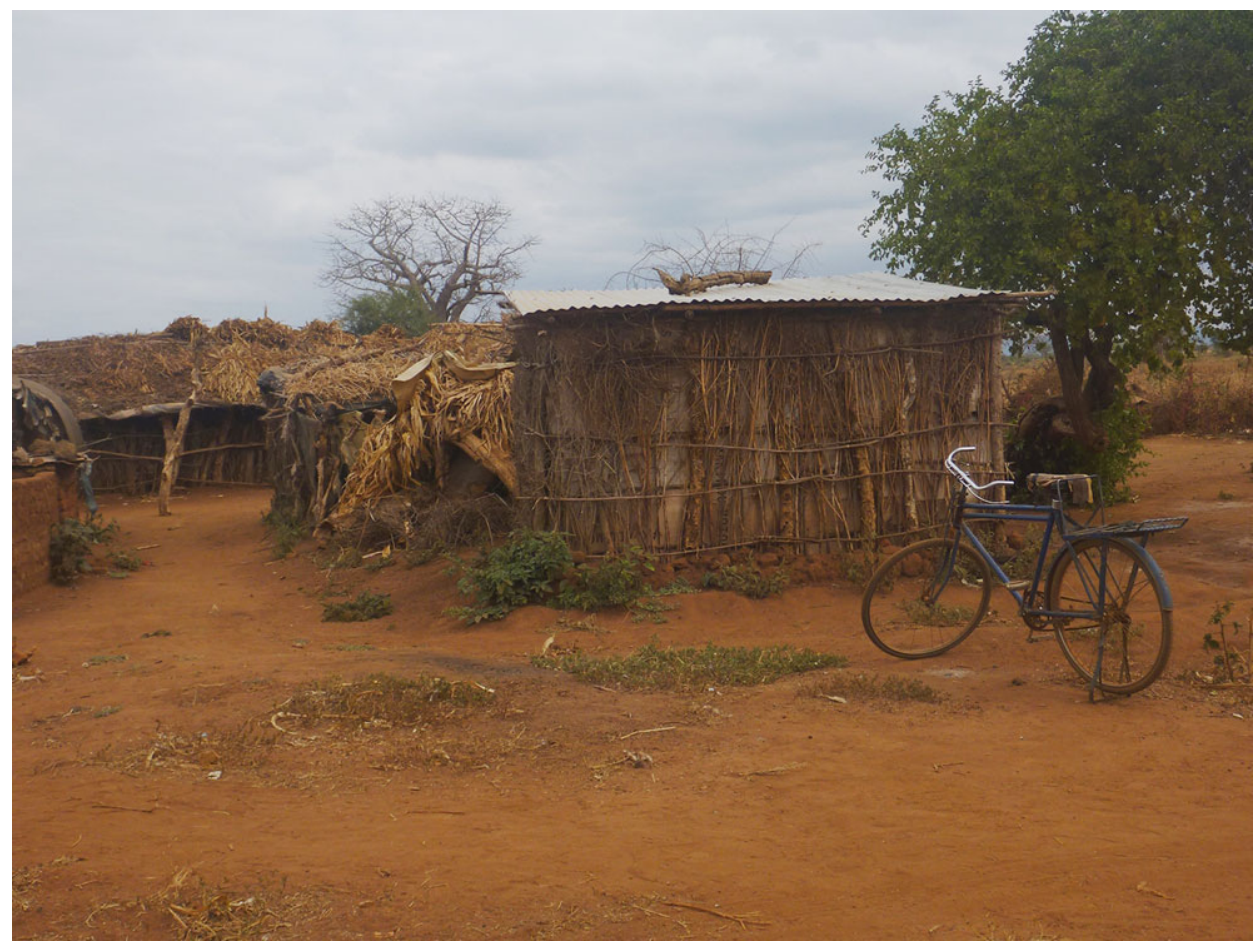

FIG. 3-Impoverished settlement near a park boundary. (Source: Photograph by the authors, June 2015).

Although biased by racist and colonial attitudes, the travel accounts and ethnographies of the earliest Europeans to visit the Tsavo region can, with caution, provide vivid descriptions of people, elephants, and landscapes (Krapf 1860; Hobley 1895; Corfield 1974).

\section{Precolonial Times: 1850-1895}

Travel accounts from the nineteenth century reveal the complex interethnic and human-elephant relations that characterized Tsavo before establishment of the British colony (Krapf 1860; Hobley 1895; Corfield 1974). The six ethnic groups shared the region using multiple land-tenure and subsistence systems, ranging across pastoralists focused on cattle, hunters and gatherers, agriculturalists, and others who variously combined such strategies. Several groups were nomadic, moving across the landscape in response to shifting hunting or pastoral conditions. The groups engaged among themselves in varying levels of conflict and exchange as well as connections to broader networks of cultural and material exchange, such as the ivory trade and interaction with Christian missionaries. People generally suffered higher mortality rates than at present due to intertribal violence, disease, and periodic famines during droughts. 
Those factors, in turn, related to differing degrees of interaction with the elephant populations that inhabited Tsavo in much greater densities than at present.

Most interethnic conflict involved cattle raids. While cattle raiding was a common practice among all groups in the nineteenth century, accounts of them often highlighted the Maasai because of the violent nature of their marauding campaigns. Maasai cattle raids increased in Tsavo during the late nineteenth century, possibly due to the growth of both their human and livestock populations and the consequent need to expand their grazing territory (Hobley 1910). These raids greatly affected the movement and activities of other tribes and, arguably, kept the overall human population from growing. One writer, rather self-servingly, speculated that only British colonialism prevented the Maasai from completely extirpating the other five groups (Hobley 1929).

Locally defined groups such as clans and families held land tenure and accorded usufruct rights to their members. Elders played a central role in settling disputes and enforcing communal rights and responsibilities. Usufruct rights were enmeshed in systems of customs, beliefs, and taboos that discouraged overexploitation. Many groups, for example, prohibited the killing of elephants and other animals without cause as a bad omen (Waithaka 2012).

Table 2-Elephant population of the Tsavo Region, 1962-2014.

\begin{tabular}{|c|c|}
\hline YEAR & ENUMERATION* \\
\hline 1962 & 40,275 \\
\hline 1965 & 20,300 \\
\hline 1967 & 25,000 \\
\hline 1969 & 23,926 \\
\hline 1970 & 30,000 \\
\hline 1972 & 25,377 \\
\hline 1973 & 20,674 \\
\hline 1978 & 5,900 \\
\hline 1988 & 5,365 \\
\hline 1991 & 8,300 \\
\hline 1989 & 6,980 \\
\hline 1994 & 7,371 \\
\hline 1999 & 9,447 \\
\hline 2002 & 9,284 \\
\hline 2005 & 11,742 \\
\hline 2008 & 11,733 \\
\hline 2011 & 12,573 \\
\hline 2013 & 11,107 \\
\hline 2014 & 11,076 \\
\hline
\end{tabular}

${ }^{\star}$ Source: KNA KW/24/32 
Nonetheless, all of the groups reported using a range of elephant parts for food, medicine, or other purposes (Kamau 2017, table 2).

Although now the smallest and most marginalized group, the Waata were central to human-elephant interactions during precolonial times. Traditionally hunter-gatherers who occupied the southern plains of TENP, neighboring groups pejoratively referred to the Waata as the Waliangulu, meaning tortoise eaters (Sheldrick 1973). A Waata man related their oral history: "Our forefathers came from Ethiopia a long time ago and settled along the Galana River. For a long time, the Waata hunted elephants for food and gathered honey. We did not cultivate crops. Most of the names used to identify places in Tsavo East National Park are Waata names. For example, Aruba is a Waata name for elephants, and Satao is a Waata name for giraffe." The dangerous hunting of elephants marked a rite of passage to adulthood for Waata males: "When a good elephant was spotted, the older men would instruct the younger men to shoot the elephant around the head. Then they would follow the elephant hoping that it would succumb to the poison in the arrows. Sometimes this was dangerous because other elephants in the herd would charge and the hunters had no choice but to run away for their safety or climb trees." Waata groups would camp around an elephant carcass until they had consumed all the meat, which together with honey provided the bulk of their diet. They developed technologies to preserve elephant meat, crushing dried meat into powder and coating it with fat and honey to prevent spoilage. The Waata also relied on landscape features that elephants created, as one woman recalled from her childhood: "When it was so dry, and the river was not flowing, elephants dug holes in sandy riverbeds to collect water. After the elephants left the hole, we would go and fetch water for cooking."

In contrast to the Waata, the Maasai and Orma were nomadic pastoralists, moving seasonally with their herds in search of pasture and water. Their mobility facilitated the coexistence of elephants and people in the same landscape, as related by a Maasai man: "the Maasai are friendly to elephants. In the past, elephants and other, smaller animals occupied areas that we abandoned as we moved around with our livestock." Such pastoralists consumed the meat, milk, and blood from their livestock as well as gathering wild plants and therefore rarely killed elephants or other wildlife for food. The Maasai, for example, only killed elephants and predators such as lions and hyenas if they posed a threat to their cattle. Moreover, they recognized and valued the ecological role of elephants in maintaining pastureland, as one Orma herder emphasized: "As elephants move through thick woodlands, they create trails which we use while grazing. It would be very difficult for herders and their animals to penetrate thorny woodlands in the absence of elephants. Also, when they knock against acacia trees the fruits drop, and these fruits provide food for the goats. Women also collect firewood from knocked down trees when they dry." 
Agricultural groups tended to incorporate some herding and hunting into their livelihoods. The Kamba, farmers who occupied the Ngulia Hills in TWNP, for example, kept some livestock, hunted elephants, and participated in the long-distance trade of tusks with Arab ivory merchants. A set of traditional rules and beliefs prevented overhunting, as related by an elderly Kamba whose father had been a prominent elephant hunter: "Prior to the day of hunting, no hunter was allowed to sleep with his wife, as this would bring bad luck. The hunters would visit a mganga [Swahili for shaman] who treated them to keep them safe from any danger. The mganga also gave instructions about where to sleep on the journey and which elephant to kill." A British official of the early colonial period, Charles Hobley, recorded that such a mganga was believed to possess powers to foretell the future. On Hobley's journey through Tsavo, a mganga prophesied that he would encounter three things: a wild animal unfit for food, a supply of food ready to eat, and a large animal. The following day the expedition first encountered a puff adder, then a pile of green bananas in an old campfire, and lastly a hartebeest (Alcelaphus buselaphus), which Hobley shot dead $(1895,552)$.

Two other agricultural groups, the Taita and Taveta, occupied a group of inselbergs between TENP and TWNP. Both groups occasionally hunted small game in the lowlands using pit traps, bows, and poisoned arrows (Krapf 1860). The Taita considered elephants to be people and attacked only those that threatened crops and human lives; even so, anyone who killed an elephant was considered to be a murderer and had to undergo a cleansing ritual.

In general, all the ethnic groups revered elephants. In part that reverence derived from how similar female elephants' two forward hanging breasts appear to those of women. But people also noted the intelligence of elephants, as one Kamba woman explained: "I believe elephants have a superior memory because they can remember the routes they used many years back. I grew up in this village, and when I was young I would see elephants immigrating from Mbirikani pass near that big tree [pointing to a large baobab tree]. They still do the same today and that's why you see the trunk of the tree is been debarked on the left side." Elephants therefore remain prominent characters in the mythology and oral literature of all the ethnic groups, as in the story of Ivonya-Ngia, which in the language of the Kamba means He Who Feeds on the Poor. Ivonya-Ngia gave a poor man an ointment and told him he would become rich if he rubbed it on his wife's teeth. The ointment caused the wife to grow tusks that the husband cut off and sold to the ivory traders. He applied the ointment again, hoping his wife would grow more ivory, but this time when she grew tusks she ran away to live in the savannah, eventually growing thick skin as well as tusks, turning entirely into an elephant. Thereafter, she lived among the elephants and birthed many calves, all of them just as intelligent as humans.

The ivory trade greatly impacted Tsavo during late precolonial times. By the nineteenth century East Africa had become a major source of ivory for 
overseas markets, and Arab and Swahili traders enlisted locals to escalate the hunting of elephants. A network of hunters, traders, and porters emerged to link Tsavo to coastal ports such as Mombasa that imported cloth and other trade goods while exporting ivory. The Waata and Kamba, in particular, became much involved in elephant hunting, and the transport and sale of ivory (Steinhart 2001). The Taita and Taveta, in contrast, became much less involved, and the Maasai and Orma barely at all. The Waata mainly hunted elephants, and the Kamba became the long-distance traders who carried the ivory hundreds of kilometers from Tsavo to Mombasa. One Kamba man suggested that ivory hunting in the nineteenth century became a response to cattle losses after droughts or Maasai raids: "My father once told me ... [that] my grandfather owned about three hundred head of cattle. There came a drought and almost all his animals died. My grandfather mobilized his friends and they went to [the Galana River] to hunt for elephant ivory. This was a few years before the arrival of Europeans. He exchanged his ivory for fifty cows and several bulls." Other interviewees also claimed that the Kamba who hunted elephants in the nineteenth century and early twentieth century primarily did so to manage the risk of crop failure rather than to accumulate wealth through the ivory trade. Moreover, in contrast to postcolonial elephant hunters, those of precolonial times would use all of the carcass rather than only extracting the tusks. Oral histories and travel accounts indicate that an additional check on overhunting elephants, and perhaps the major reason the elephant population did not dramatically decline during the nineteenth century, involved the militaristic domination of large areas of the lowlands by the Maasai, who did not hunt elephants themselves and thereby prevented much Kamba and Waata hunting (Hobley 1895).

A devastating rinderpest epidemic in 1890 radically transformed the relationships between the ethnic groups, livestock, elephants, and vegetation. By 1892, the Maasai had lost about two-thirds of their herds, crippling their social dominance (Tyrrell 1985, 1987). The major drought that followed the epidemic precipitated depopulation and abandonment of pastures and croplands (Hobley 1895).

\section{Colonial Times: $1895-1963$}

Due to the rinderpest epidemic and drought in the 189os, by the end of the nineteenth century the Tsavo lowlands appeared to Europeans to be an uninhabited wasteland (Hobley 1895). Kamba oral history describes the period between 1898 and 1902 as the worst drought in memory. Ultimately, the epidemic and drought ended Maasai dominance in Tsavo and facilitated the establishment of colonial rule in Kenya. The British declared Kenya a protectorate in 1895 and the Imperial British East African Company (IBEAC) built a railway through Tsavo in 1901, not due to much interest in that area per se but to connect Lake Victoria to Mombasa and thereby secure control of the headwaters of the Nile River. 
Most immediately, the railway cut elephant migration trails; just as critically, however, it opened the area up to colonial settlement. Ordinances declared all land in the protectorate to be Crown land and recognized African land claims only by agricultural and pastoral groups, not by hunters and gatherers (Wijngaarden 1985). All lands outside of the native reserves established through those ordinances became available for British settlers to establish sisal plantations and other types of private farms along the railway, lands formerly the elephant hunting grounds of the Waata and Kamba and the dry-season pastures of the Maasai and Orma.

As early as 1910, the colonial administration claimed ownership of all wildlife, including elephants. The establishment of the Kenya Game Department ushered in an era of big-game hunting, overlaying settler colonialism with European sport hunting (Hunter 1952; Mackenzie 1988). One Taita informant related the history of that period: "So many elephants were eliminated by hunters and the game department. We were told the government was eliminating the elephants and other wildlife to allow farming to take place in the lowlands. Wildlife, especially elephants, were eliminated to establish sisal plantations in Voi, Bura and Mwatate." According to colonial regulations, only licensed hunters who owned firearms could legally hunt (Parker and Amin 1983). The costs involved effectively outlawed hunting by most Africans, and colonial officials regarded those who hunted anyway to be poachers subject to fines, arrest, and incarceration. That new regulatory regime increasingly alienated Africans from elephants, both materially and symbolically. As the European population of Kenya increased and settlers occupied more land, the British proclaimed in 1920 that the protectorate had become a colony and, in 1926, that all land occupied by African groups must be surveyed and the boundaries of the reserves registered. Then, in 1934, the Kenya Land Commission (KLC) began to reserve sparsely settled lands for wildlife conservation and, in 1948, consolidated some of them to found Tsavo National Park, eventually to become TENP and TWNP (KLC 1934; Kenya National Archives [hereafter, KNA] NPK 16/7/Vol. 11).

Former British military officers, entirely without expertise in natural resource management, became the first park wardens and applied an intuitive, commonsense approach (Schauer 2015). Their first priority involved the expulsion of all human inhabitants. Although colonial records depict park evictions as peaceful, local narratives suggest violence by government officials and strong resistance by Waata and other groups (KNA NPK/16/1/4008). Their oral histories record the role of David Sheldrick, the first warden of TENP.

We had given [Sheldrick] the name saa nane [Swahili for two o'clock] because all his meetings with local people were held at 2:00 pm. He came to Ndololo and told our elders that the place we had settled belonged to the government. Our elders told the people to disobey him. He mobilized a team of security personnel and vehicles to drive us out. They forced us into the trucks and 
set all our huts on fire.(Interview with a male Waata elder near Voi town on June 15, 2015)

Wardens targeted Waata and Kamba hunters with antipoaching squads that employed the same military techniques used to suppress the 1952-1956 MauMau Rebellion in central Kenya (Steinhart 1994). As one Waata man recalled, hunters were gunned down in the parks or arrested after being tracked to their homes outside park boundaries. By 1957, the campaign against the remaining elephant hunters had been completed and pronounced to be the most successful antipoaching operation in all of Africa (Schauer 2015).

Establishment of the parks greatly impacted the ethnic groups that had previously inhabited TENP and TWNP. Despite their differences, the colonial government treated all largely the same-as an unwelcome presence on the landscape and a threat to elephant populations. They variously suffered loss of land, resettlement in fractious multicultural settings, impoverishment, and diminished ability to hunt, grow, and gather food and other resources, including their long-standing relationships with elephants. Religious conversions to Christianity and Islam also changed many local beliefs and practices in relation to elephants. The Waata, who had previously relied so much on elephant hunting, suffered a sharp decline in population after losing their customary hunting rights. Narratives from Waata informants indicate the Waata elephant hunters who could not adapt to grain-based diets suffered malnutrition and death. The Waata also partly lost their ethnic identity when the national census began to enumerate them as Taita. The Taita were relocated from their fertile, humid inselbergs to semiarid lowlands yet banned from customary hunting, leaving them with marginal croplands vulnerable to damages by elephants straying beyond park boundaries and Maasai livestock raids. In general, relocation and disruption of long-standing lifeways forced many into the labor market, most often to work on sisal plantations or railway construction. The resulting widespread poverty pushed Waata, Kamba, and others to risk arrest or death to enter the parks to hunt elephants for ivory.

The pastoralist Maasai, who had long shared the landscape with elephants rather than hunting them, fared somewhat better. Because the colonial administration recognized land claims based on grazing, the Maasai were permitted to continue to enter some areas within the parks to water their livestock. The oral histories reveal how the political power of the Maasai, a legacy of their militaristic dominance of Tsavo in precolonial times, persisted during colonial times. In contrast, the livelihoods of ethnic groups that had relied on hunting and gathering became entirely illegal within park boundaries.

In summary, most of the land set aside for conservation in Tsavo was appropriated during the colonial period. The creation of protected areas in Tsavo involved the displacement of local people and dispossession of their land. Parks had a dramatic impact on land ownership in Tsavo. For instance, 62 percent of landmass of Taita Taveta County is under Tsavo National Park. 
Some of the land included in the national park was traditional seasonal grazing land for the Taita and Maasai. The creation of Tsavo National Park reduced the grazing and hunting range, thus negatively impacting on the subsistence strategies of local people. By the 1960s, Tsavo was a mosaic of different land uses and tenure shaped by colonial land policies. National parks, large commercial sisal farms, government owned forest reserves, which covered about 80 percent of total land in Tsavo were adjacent to small-holder agricultural plots and group ranches. When Kenya attained independence in 1963, traditional communal ownership of land in Tsavo had been replaced with individualized freehold ownership. This set the stage for human-elephant conflict in Tsavo. As elephants strayed from national parks and group ranches to raid crops in private small-holder farms, farmers increasingly became less tolerant of elephants in their private lands.

\section{Postcolonial Times: 1963-Onwards}

Kenya gained independence from Britain in 1963, but the newly sovereign, postcolonial government largely perpetuated the material and discursive characteristics of colonial nature/society governance. Elephants and other wildlife remained the property of the state and concentrated within parks. The human inhabitants of Tsavo remained disconnected from their precolonial land uses and the elephants. Each successive postcolonial government has further indurated such colonial discourse and practice. In 1983, the government established CHNP and thereby further increased regional landlessness, poverty, and resource conflicts (Kamau and Medley 2014). At the same time, people from other regions of Kenya moved to the Tsavo region because of easier transportation access, the growth of regional towns, and expanding charcoal and tourism industries.

The resulting landscape transformation within the parks derived from the inextricable relationships among humans, elephants, livestock, and vegetation (Botkin 1990). Excluded from the three parks, people increasingly settled just outside their boundaries, in part to work in the growing tourism industry that included private trophy-hunting estates and game safaris (Sheldrick 1975). Elephants, in turn, gravitated toward the parks, particularly TENP, as a space safe from hunters. Even by the 1960s, elephant population and density had increased within the parks to the point that the woody vegetation they consume had begun to suffer from uprooting and overbrowsing, resulting in starvation and malnutrition not just among elephants but also other browsers such as rhinoceroses (Table 2) (Laws 1970, 1971; KNA KW/24/32). An estimated 300 black rhinoceroses died of starvation in 1960 alone (Leuthold 1996; KWS 2012; Parker and Amin 1983). By the late 1960s, open grasslands had replaced large areas of woodland (Leuthold and Sale 1973). When another severe drought occurred in 1970-1971, some 9,000 elephants died of starvation and thirst (Sheldrick 1973). Despite debates over culling elephant populations to control these effects, conservation strategies continued to prioritize an imagined pristine 
nature within the boundaries of parks that would bring their ecosystems back into a putative equilibrium (Schauer 2015).

The drought also resulted in changes to human use of the parks. The Kamba, Maasai, and Orma suffered massive livestock losses. Somalis, whose livestock had also been severely affected by the drought, begun migrating to Tsavo in large numbers in search of pasture. As their livestock died, locals and migrants alike began collecting ivory from the elephant carcasses that littered the parks. When that "found ivory" ran out, they began killing elephants. One Kamba man recalled that period.

One day in 1975, on an early morning, my neighbor and I entered Tsavo West National Park to collect ivory from elephants that had died of drought. We did not find any ivory to collect. On our journey back, we saw two fresh elephant carcasses, whose ivory had been chopped off. It was clear that the elephants had been shot for ivory. I did not go to the park again, but in the next few weeks I heard stories about rampant killing of elephants until a ban on hunting was put in place by the government in 1977. Most of those who killed elephants with guns came from other parts of the country(Interview with a male Kamba elder in a village near the Galana River on July 10, 2015).

Over the 1970s, the killing of elephants for ivory continued, decimating their population. A 1973 presidential ban on elephant hunting and a 1977 ban on all hunting without a permit only resulted in a dramatic increase in ivory prices, from three Kenya shillings (currently valued at approximately US\$0.03) per kilogram in the 1960 s to a hundred (US\$1.00) in the 1970s, and a consequent increase in elephant hunting (Parker 2004). Moreover, the open grasslands precipitated by the large elephant population of the 1960s only facilitated hunting. Combined with the loss of historical practices that maintained balanced relationships among humans, elephants, livestock, and vegetation the poaching boom devastated the elephant population, reducing it from some 30,000 in 1970 to 6,980 in 1989 . Urban elites and corrupt government officials profited the most from the booming black market in ivory (Hall 1995). Their profits relied on local and migrant poachers motivated by crop failures and livestock loss, but those hunters bore the greatest risk while earning a mere tenth as much per kilogram of ivory as it ultimately sold for on foreign markets.

During this period, the spatial restructuring of human and elephant land use and mobility, environmental degradation, extension of the cash economy, and increasingly militaristic poaching and antipoaching tactics, resulting in an "arms race between poachers and antipoaching forces," contributed to a new mode of human-elephant relations (Lunstrum 2014, 817). Humans were to be fixed in place outside of park boundaries; elephants and other wildlife were protected and thereby encouraged to roam freely across space, transgressing park boundaries at will. A rapidly increasing human regional population resulted in such an expansion of cropland around the parks that farmers and elephants increasingly competed for space, water, and plants. The unequal 
power relations among local peoples, the state, and elephants precipitated the types of conflicts reported by a Taveta man.

When we take our animals to the park for grazing, the KWS rangers are quick to arrest us, but when wildlife come to our farms, they do not rush to drive them out. In fact, we always wonder why when an elephant kills someone, the KWS people are not in a hurry to arrive but when one elephant dies you see many cars and helicopters coming within a short time. People here suffer from elephants(Interview with a male Taveta informant in a village near Taveta town on July 22, 2015).

The perceived Maasai privilege regarding grazing within parks has nonetheless persisted, to some degree at least, as one Kamba reported: "The Maasai are not arrested when they graze in the national parks, while the Kamba are constantly harassed for doing the same." A Maasai woman, however, claimed that even they had suffered reduced access to grazing within the parks while elephants freely entered their pastures just outside the boundaries.

Before Maasailand was divided into group ranches, we could move around with our animals freely to the Chyulu Hills, areas around the Amboseli [a small national park just west of CHNP], and parts of Tsavo. When the group ranches were formed people became selfish and you need permission to graze in another group ranch. However, wildlife roam freely in the group ranches and follow no boundaries(Interview with a female Maasai informant in Mbirikani Group Ranch on June 15, 2015).

Since 1990, the KWS has once again attempted to restructure human-elephant spatial relations and mobility. In response to increased conflict between elephants and farmers, the KWS is installing electric fences to fix elephants in space, to fence them into the parks as a counterpart to keeping humans out of parks. As Leakey stated in an interview on Kenyan Television Network in June 2016, "We are moving to a point where these parks have to be fenced .... We will have to in the next few years engage in a massive programme, with hundreds of millions of dollars to put game-proof fences along the boundaries." Indeed, these barriers have significantly reduced the movement of elephants into farms as well as human encroachment into parks. The ecological consequences of the fences remain unclear, however. They block the migration routes of elephants and other species, reduce elephant ranges, and prevent access to critical water sources during the dry season. Some scientists are concerned that the fences will even create insular elephant populations that result in loss of genetic viability and local overpopulation and overbrowsing (Martha Munyao, pers. com., 23 July 2015).

Along with fences have come massive ivory bonfires, media-driven spectacles of antipoaching politics. The first of these took place in 1989, when Kenyan President Daniel Moi torched a twelve-ton stockpile of confiscated elephant ivory worth an estimated US\$3 million. Leakey had convinced Moi that burning ivory would deter elephant poaching (Leakey and Morell 2001). Similar 
ivory bonfires were conducted again in 2011, 2015, and 2016-the latest being the largest ever and presided over by President Uhuru Kenyatta-and other countries have followed that example.

While burning ivory garners widespread attention by the international media and praise from many conservationists, critics point out that these countries could use the potential earnings from confiscated ivory to support better conservation programs. Funds could be used to improve park management, compensate victims of crop damages, or fund development of poor communities that neighbor the parks. One Waata participant pointed out the irony inherent in ivory bonfires.

In the past, the park officials would kill an animal during national celebrations and people would be given the meat. We don't see that happening nowadays. I remember when Jomo Kenyatta visited Voi, he was entertained by the local dancers and then he ordered the warden to give us meat. These days we wonder why the government burns ivory when people are suffering in the villages (Interview with a female Waata elder in a village near Maungu town on December 6, 2015.

The establishment of the national parks in Tsavo had a major impact on human-elephant relations. Park creation involved the displacement of local people and dispossession of their land. Parks therefore had a dramatic impact on land ownership in Tsavo. For instance, $62 \%$ of landmass of Taita Taveta County is under Tsavo National Park. Some of the land included in the national park was traditional grazing land for the Taita and Maasai. The creation of Tsavo National Park reduced the grazing and hunting range thus negatively impacting on the subsistence strategies of local people. By the 1960s, Tsavo was a mosaic of different land uses and tenure shaped by colonial land policies. National parks, large commercial sisal farms, and government owned forest reserves that cover about 80 percent of total land in Tsavo were adjacent to small-holder agricultural plots and group ranches. This set the stage for human-elephant conflict in Tsavo. Elephants stray from national parks and group ranches to raid crops in private small-holder farms.

\section{"People Here Suffer From Elephants"}

The oral histories together with complementary archival and published sources reveal how elephant-human-landscape relations have transformed over the past two centuries. The general trend has involved a transformation from a precolonial modality characterized by mobility to increasing spatial separation and immobility through colonial and postcolonial times. A colonial triangle model, modified from previous applications in the Americas (Sluyter 2002; Colten 2014), illustrates the transformations involved (Figure 4). Each of the three elements of the triangle-people, landscape, and elephants - encompasses a material and a discursive/conceptual moment. The relational processes that connect the three elements precipitate their transformation. 


\section{Colonial Triangle for Human-Elephant-Landscape Interaction \\ Material \\ Discuns:Ine/Conceptual \\ $(\ldots \cdots \cdots \cdot \cdots)$ Expanding electric fences \\ Selected interactions \\ Weakening interactions

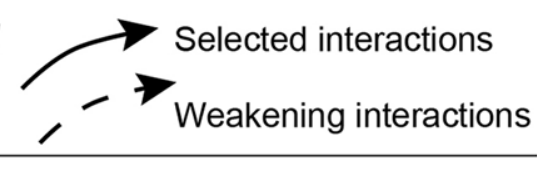

\section{Precolonial}

High mobility and

spatial interaction

Natur:/SOGIீ@ty

People

\section{Nature/SoGiety}

Landscape

(savannah with mix of grass-, shrub-, and woodland)

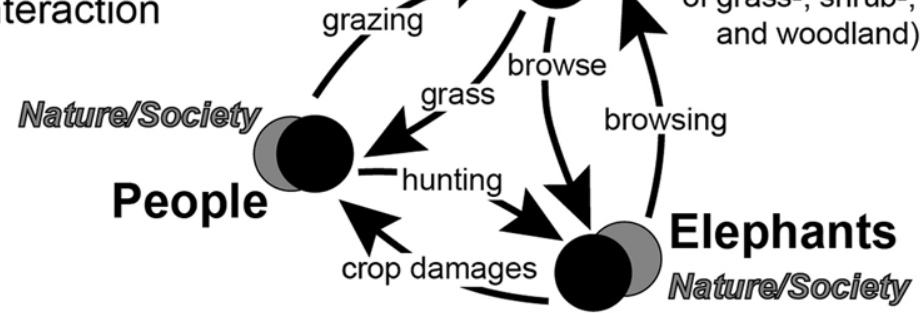

\section{Colonial}

Reduced mobility and spatial interaction

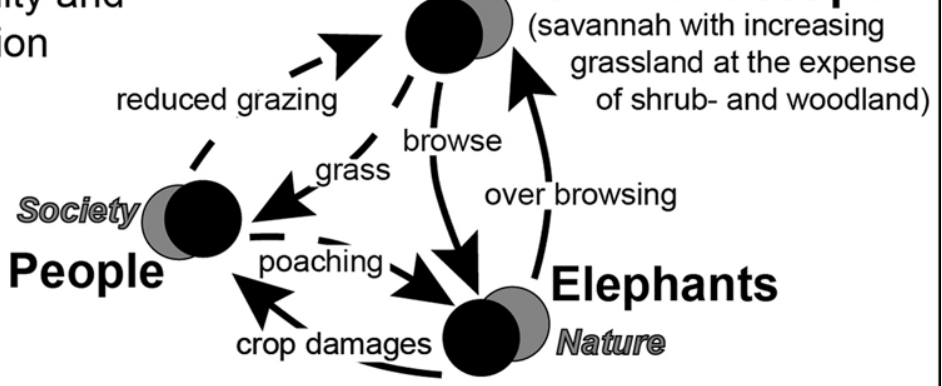

\section{(Post)colonial}

Virtual elimination of mobility and spatial integration

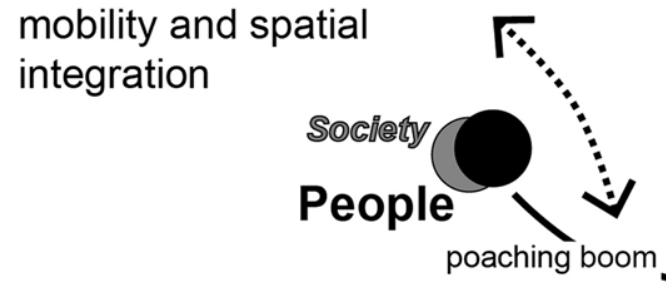

\section{Nature}

Park Landscape (grassland becomes dominant)

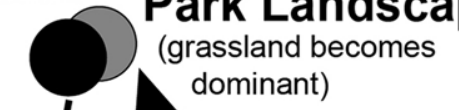
(Source: See text for data. Drafted by the authors, 2017). 
During precolonial times, the mobility of people, livestock, and elephants across the landscape promoted mixed woody and herbaceous vegetation. Kamba and Waata hunters limited the population of elephants to use them for food and many other purposes, but had no reason to begin overhunting them until the ivory trade reached Tsavo in late precolonial times. Maasai and Orma herders did not normally hunt elephants at all, instead relying on the trails they cleared through the thorny shrubland to drive their herds to new pastures, the waterholes elephants dug in dry riverbeds, and elephant dung to cure illnesses among their herds. Taita and Taveta protected their crops from elephants that came to their hill farms to forage, but considered killing one to be murder. Discursively, people, landscape, and elephants all pertained to a single nature/ society nexus.

Colonialism reduced that mobility. Initially, the Mombasa-Uganda Railway inadvertently cut the elephant migration trails that crossed the Tsavo region. The establishment of parks soon thereafter, however, dramatically decreased human mobility by resettling them outside of park boundaries, prohibiting their use of park resources, and reducing elephant hunting and livestock grazing within park boundaries. By late colonial times, the resulting high elephant density caused overbrowsing and the expansion of grassland at the expense of shrub- and woodland. Increases in cropland and sisal plantations just beyond park boundaries further limited elephant mobility at the same time as increasing human conflict with elephants that raided farms in search of browse. The discursive segregation between people as the social element and the park landscape and elephants as natural elements had begun to supplant the precolonial nature/society nexus.

Postcolonial relationships between elephant and human inhabitants of Tsavo have only deteriorated further as elephants have gained powerful political patrons and greater social power than farmers and herders. They, in turn, have resisted their political marginalization by protesting for crop-damage compensation, indifference towards antipoaching efforts, and condoning members who trespass in parks to collect wood, graze livestock, and poach for ivory and bush meat. The response has increasingly involved electric fences to decisively segregate people from the elephants and park landscapes.

Those material and performative transformations parallel the discursive purification of the parks from a natural/social landscape into a putatively natural landscape. Colonial efforts to divide the social from the natural along park boundaries, however, were doomed from inception because human, elephant, livestock, and vegetation agencies had already been entangled for millennia. Precolonial people, livestock, elephants, and vegetation had long interacted to create the landscape that the colonial park managers hoped to preserve by removing people and livestock.

As a result, some inhabitants of the park environs do not view themselves as the allies of elephant conservationists. The respectful, even reverential among 
some groups, human-elephant relations of precolonial times have become vestiges of oral histories. Instead, elephants have become a symbol of state monopoly over resources and perceived as politically favored and a threat to human livelihoods that causes suffering.

\section{Electric Fences or Park Humanization}

Tsavo will continue to present new challenges for humans and elephants. Based on current trends, human population growth due to natural increase and migration will create the potential for even more human-elephant conflict. In addition, a new railway under construction between Mombasa and Nairobi will further divide TENP from TWNP. Electric fences will keep wildlife out of the railway corridor, with elephants able to cross only via underpasses that will funnel them through limited areas and promote overbrowsing. The fences will, concurrently, further exclude people from the parks and potentially mitigate human-elephant conflict by keeping elephants from damaging crops.

Such normalization of electric fences conforms to, and takes to the extreme, the conservation model that emerged in colonial times: exclude people from parks to purify nature on one side of the fence and society on the other. It imagines elephants to be touristic resources to be viewed rather than social actors to interact with. Increasingly, the local ethnic groups as well as the immigrants from elsewhere in East Africa, have conceded to that prevalent discourse and come to view elephants as distinct from society, but as competitors for resources and/or as a resource that can provide marketable ivory rather than as a resource for tourism.

\section{CONCLUSION}

Reconstructing oral histories provides a dual path toward reversing that costly, destructive conservation model and recruiting people who live adjacent to conservation areas to become allies in protecting elephant populations. Recruitment of local people can be realized through comanagement plans between park neighbors and the KWS. Comanagement plans in natural resource management recognize that stakeholders who have a claim to a certain natural resource should share rights and responsibilities of managing such a resource (Colfer 2005). This study and other studies conducted in Tsavo indicate that local people support opportunities to work with the KWS to resolve resource use conflicts (Kamau and Medley 2014). By using oral histories, this study gave local people in Tsavo an opportunity to contribute their knowledge on humanelephant conflicts in their landscape.

For one, oral histories preserve the traces of more spiritual and social relationships with elephants that date to precolonial and early colonial times. These memories provide alternatives to a future of fences, surveillance, and violent confrontations between elephants, local peoples, and the KWS. Secondly, oral histories historicize the current divide between nature and society, revealing it 
to be abnormal within the long-term, millennial relationship between people and elephants in East Africa. It thereby provides insights into how to reestablish the norm by humanizing parks. Some sort of utopianist "return" to precolonial landscapes remains both impossible and undesirable. But reintegrating human activities such as livestock grazing in designated areas, firewood gathering as normal, and ecologically benign uses of parks provides a constructive alternative to building fences that immobilize and spatially separate people and elephants.

In this paper we have analyzed the historical emergence of human-elephant conflict in Tsavo using oral histories and other records. The paper stresses that conflicts between elephants and people in Tsavo can only be properly understood by examining landscape transformations that took place in the region from the colonial period to the present. The findings of this study are corroborated by other studies which show that Africa's colonial land transformations laid the foundation for modern day attitudes towards wildlife (Lee and Graham 2006; Adams and Hutton 2007; Sifuna 2009). Like other research conducted around elephant ranges in Africa, this study points to the complex interactions between elephants and people (Infield and Namara 2001; Omondi and others 2004; Ngene 2010). Currently, elephant-proof electric fences are being used to mitigate conflict between people and elephants. Since electric fences have social and political implications, we recommend that local communities are actively involved in their implementation. Research has shown that positive attitudes towards elephants are stronger where there is involvement of local residents (Kamau 2017).

\section{REFERENCES}

Adams, W. M. 2003. Nature and the Colonial Mind. In Decolonizing Nature: Strategies for Conservation in a Post-Colonial Era, edited by W. M. Adams and M. Mulligan, 16-50. London: Earthscan Publications.

Adams, W., and J. Huttons. 2007. People, Parks and Poverty: Political Ecology and Biodiversity Conservation. Conservation and Society 5 (2): 147-183.

Akama, J. S., C. L. Lant, and W. Burnett. 1996. A Political-Ecology Approach to Wildlife Conservation in Kenya. Environmental Values 5 (4): 335-347.

Botkin, Daniel. 1990. Discordant Harmonies. A New Ecology for the Twenty-First Century. New York: Oxford University Press.

Brechin, S. R., P. R. Wilhusen, C. L. Fortwangler, and P. C. West. 2003. Contested Nature: Promoting International Biodiversity with Social Justice in the Twenty First Century. New York: State University of New York Press.

Corfield, M. 1974. Historical Notes on Tsavo. Nairobi: Tsavo Research Project, Kenya National Parks.

Colfer, J. P. C. 2005. The Complex Forest: Communities, Uncertainty and Adaptive Collaborative Management. Washington D.C. Resources for the Future, Bogor, Indonesia. Center for International Forestry Research.

Colten, C. E. 2014. Southern Waters: The Limits to Abundance. Baton Rouge: Louisiana State University Press.

Hall, R. 1995. Improving Public Sector Performance in Natural Resources Management. The Kenya Wildlife Service: A Case Study of Parastatal Organization. Tucson: Office of Arid Lands, University of Arizona. 
Hobley, C. W. 1895. Upon a Visit to Tsavo and the Taita Highlands. The Geographical Journal 5 (6): 545-561.

-1910. Ethnology of Kamba and other East African Tribes. Cambridge: Cambridge University Press.

- 1929. Kenya, from Chartered Company to Crown Colony: Thirty Years of Exploration and Administration in British East Africa. London: H. F. \& G. Witherby.

Hoare, R. E., and J. T. Du Toit. 1999. Coexistence between People and Elephants in African Savannahs. Conservation Biology 13 (3): 633-639.

Hunter, J. A. 1952. Hunter. London: Hamish Hamilton.

Infield, M., and A. Namara. 2001. Community Attitudes and Behavior Towards Conservation: An Assessment of a Community Programme around Lake Mburu National Park, Uganda. Oryx 35 (1): 48-60.

Kamau, P. N. 2017. Elephants, Local Livelihoods, and Landscape Change in Tsavo, Kenya. PhD diss., Louisiana State University.

- 2017. The Political Ecology of Human-Elephant Relations: Comparing Local Perceptions of Elephants around Chyulu Hills and Mount Kasigau in Southern Kenya. Journal of Political Ecology 24:2017.

-., and K. E. Medley. 2014. Anthropogenic Fires, and Local Livelihoods at Chyulu Hills, Kenya. Landscape and Urban Planning 124 (April): 76-84.

Kasiki, S. M. 1998. Human-Elephant Conflict in Areas Adjacent to Tsavo National Parks, Kenya. $\mathrm{PhD}$ diss., University of Kent.

Kenya Land Commission (KLC). 1934. Land Commission Evidence, Vol. III, Coast Province. Nairobi: Kenya National Archives.

Kenya National Bureau of Statistics (KNBS). 2010. The 2009 Kenya Population and Housing Census: Counting our People for the Implementation of Vision 2030. Nairobi: Government Printers.

Kenya Wildlife Service (KWS). 2008. Tsavo Conservation Area: Management Plan 2008-2018. Nairobi: KWS.

Kenya Wildlife Service (KWS). 2012. Annual Report 2012. Nairobi: KWS.

Krapf, L. 1860. Travels, Researches and Missionary Labors During an Eighteen-Year Residence in Eastern Africa. London: Frank Cass.

Laws, R. M. 1970. Elephants as Agents of Habitat and Landscape Change in East Africa. Oikos 21 (1): 1-15.

- 1971. The Tsavo Elephants. Oryx 11 (1): 32-34.

Leakey, R., and V. Morrell. 2001. Wildlife Wars: My Fight to Save Africa's Natural Treasures. New York: St. Martin's Press.

Lee, P. C., and M. D. Graham. 2006. African Elephants Loxodonta africana and HumanEnvironment Interactions: Implications for Conservation. International Zoo Yearbook 40 (1): 9-19.

Lepp, A., and S. Holland. 2006. A Comparison of Attitudes toward State-Led Conservation and Community Based Conservation in the Village of Bigodi, Uganda. Society and Natural Resources 19 (7): 609-623.

Leuhold, W., and J. Sale. 1973. Movement and Patterns of Habitat Utilization of Elephants in Tsavo National Park. African Journal of Ecology 11 (3/4): 369-384.

Leuthold, W. 1996. Recovery of Woody Vegetation in Tsavo National Park, Kenya, 1970-94. African Journal of Ecology 34 (2): 101-112.

Lunstrum, E. 2014. Green Militarization: Anti-Poaching Efforts and the Spatial Contours of Kruger National Park. Annals of the American Association of Geographers 104 (4): 815-832.

Mackenzie, J. M. 1988. The Empire of Nature: Hunting, Conservation and British Imperialism. Manchester, UK: Manchester University Press.

Moore, L. 2009. The Neo-Liberal Elephant: Exploring the Impacts of the Trade Ban in Ivory in the Commodification and Neoliberalisation of Elephants. Geoforum 42 (1): 51-60.

Neumann, R. 1998. Imposing Wilderness: Struggles over Livelihood and Nature Preservation in Africa. Berkeley: University of California Press.

Ngene, S. 2010. Why Elephants Roam? University of Twente. ITC dissertation number 171. 
., S. Njumbi, M. Nzisa, K. Kimitei, J. Mukeka, S. Muya, F. Ihwagi, and P. Omondi. 2013. Status and Trends of the Elephant Population in the Tsavo-Mkomazi Ecosystem. Pachyderm 53 (1): 38-50.

Njogu, J. G. 2004. Community-Based Conservation in an Entitlement Perspective: Wildlife and Forest Biodiversity Conservation in Taita, Kenya. Leiden, the Netherlands: African Studies Center.

Omondi, P., E. Bitok, and J. Kagiri. 2004. Managing Human Elephant Conflicts: The Kenyan Experience. Pachyderm 36:80-86.

Parker, I. S. 2004. What I Tell You Three Times is True: Conservation, Ivory, History and Politics. Oryx 39 (1): 99-100.

—., and M. Amin. 1983. Ivory Crisis. London: Chatto and Windus.

Paraskevopoulos, S., K. J. Korfiatis, and J. D. Pantis. 2003. Social Exclusion as Constraint for the Development of Environmentally Friendly Attitudes. Society and Natural Resources 16 (9): 759-774.

Robbins, P. 2004. Political Ecology: A Critical Introduction. Oxford: Blackwell Publishing.

-, K. McSweeney, A. K. Changani, and J. L. Rice. 2009. Conservation As It Is: Illicit Use in a Wildlife Reserve in India. Human Ecology 37 (5): 559-575.

Schauer, J. 2015. The Elephant Problem: Science, Bureaucracy, and Kenya's National Parks, 1955 to 1975. African Studies Review 58 (1): 177-198.

Sheldrick, D. 1973. Animal Kingdom: The Story of Tsavo, the Great African Game Park. New York: Bobbs-Merrill.

Sifuna, N. 2009. Damage caused by wildlife: Legal and institutional arrangements. Environmental Policy and Law 39 (2): 105-127.

Sluyter, A. 2001. Colonialism and Landscape in the Americas: Material/Conceptual Transformations and Continuing Consequences. Annals of the American Association of Geographers 91 (2): 410-429.

- 2002. Colonialism and Landscape: Postcolonial Theory and Applications. New York: Rowman and Littlefield.

Steinhart, E. I. 2001. Elephant Hunting in the $19^{\text {th }}$ Century in Kenya: Kamba Society and Ecology in Transformation. The International Journal of African Historical Studies 33 (2): 335-349.

Tyrrell, J. G. 1985. The Distribution of Elephants in the Tsavo Region during the $19^{\text {th }}$ Century. African Journal of Ecology 23 (1): 29-33.

- 1987. Reconstructing $19^{\text {th }}$ Century Vegetative Patterns in Kenya. Geographical Review 77 (3): 293-308.

Waithaka, J. 2012. The Kenya Wildlife Service in the $21^{\text {st }}$ Century: Protecting Globally Significant Areas and Resources. The George Wright Forum 29 (1): 21-29.

Wijngaarden, W. 1985. Elephants, Trees, Grass, and Grazers: Relationships between Climate, Soils, Vegetation and Large Herbivores in a Semi-Arid Savannah Ecosystem (Tsavo, Kenya). Enschede, the Netherlands: International Institute for Aerospace Survey and Earth Sciences. 